\title{
Turbulencje systemu bankowego w Rosji w warunkach pandemii SARS-CoV-2
}

Turbulence of the banking system in Russia in the conditions of the SARS-CoV-2 pandemic

\section{Wprowadzenie}

System bankowy w Rosji już w pierwszych miesiącach 2020 r. zaczął odczuwać konsekwencje gwałtownie rozprzestrzeniającej się pandemii koronawirusa SARS-CoV-2. Celem niniejszego tekstu jest zaprezentowanie tych następstw w kontekście odporności sektora bankowego w Rosji na zjawiska kryzysowe. Przedmiotem badania będą hipotezy:

1. Gospodarka Rosji jest silnie uzależniona od zmian cen surowców energetycznych, które w ostatnim czasie są na niskim poziomie.

2. Sektor bankowy w Rosji w ostatnich latach stabilizuje się, jednak wymaga niezbędnych korekt.

3. Dynamika zmian nie jest wystarczająco adekwatna do zmieniającego się otoczenia gospodarczego i społecznego.

Do przygotowania artykułu wykorzystano oficjalne informacje publikowane przez Bank Rosji i Federalną Służbę Państwowej Statystyki. Przeanalizowano i poddano krytycznej ocenie opracowania naukowe na temat ewolucji rosyjskiego sektora banków komercyjnych.

\section{Sytuacja makroekonomiczna w Rosji}

Analizując zmiany w sektorze bankowym, należy zauważyć, że w czasie przed wybuchem pandemii w Rosji stabilizowała się makroekonomiczna sytuacja 
gospodarcza. Wzrost gospodarczy w 2019 r. utrzymywał się na poziomie 1,9\% wobec 2,5\% w 2018 r. oraz 1,6\% w 2017 r. Jeżeli w 2016 r. PKB osiągnął wartość 83 087,4 mld rubli, to w następnych latach systematycznie wzrastał, by za $2019 \mathrm{r}$. wynieść 110 046,1 mld rubli (RosStat, 2020a). Głównym źródłem wzrostu gospodarczego był rosnący eksport towarów i usług. Jednak struktura wymiany handlowej Rosji z zagranicą nie jest korzystna, dominują przychody z eksportu surowców energetycznych (Kamiennikow, 2015). Ich ceny w ostatnim czasie gwałtownie spadały. Stabilna i korzystna była jednak sytuacja na rynku pracy. W ostatnich latach stopa bezrobocia zmniejszała się z 7,3\% w 2017 r. do 5,5\% w 2018 r. oraz do 4,9\% w 2019 r. (Visanam, 2020). Średnia miesięczna płaca nominalna rosła z 20952 rubli w 2010 r. do 42550 rubli w 2018 r. Realne dochody ludności zwiększały się jednak nieznacznie - w $2018 \mathrm{r}$. wzrosły minimalnie o 0,3\% (RosStat, 2020b). W 2020 r. średnie zarobki znalazły się na poziomie 48,648 rubli (Yandex, 2020a). Można było zauważyć istotne różnice regionalne w dochodach ludności. Mieszkańcy Moskwy zarabiali w tym czasie 88900 rubli. Przyczyną takiego stanu rzeczy była coroczna indeksacja zarobków urzędników krajowej administracji publicznej pracujących głównie w stolicy. Utrzymywała się dynamika inwestycji w kapitał podstawowy. Do końca 2019 r. rosła produkcja przemysłowa - w 2019 r. o 2,9\% wobec 2,1\% w 2018 r. (Ministerstwo Ekonomiczieskowo, 2020a). W istotnym stopniu ten stan rzeczy wynikał z utrzymującej się regularnej dynamiki wzrostu wydobycia ropy naftowej i węgla oraz rosnącej eksploatacji gazu. Nie jest to sytuacja korzystna, ponieważ wzrost gospodarczy w Rosji oparty jest nadal w znaczącym stopniu na wydobyciu bogactw naturalnych, a w niewielkim stopniu na zwiększającej się produkcji przemysłowej czy usługach, nie mówiąc już o poprawie innowacyjności gospodarki (Iwasienko, Ikonowa, 2020). Dynamika popytu wewnętrznego stabilizowała się na poziomie $2,6 \%$ w skali roku i wynikała w dużym stopniu ze wzrostu płacy minimalnej. Korzystnie w ostatnich latach kształtowały się wskaźniki inflacji, na poziomie ok. 4-5\% w skali roku (Andrianow, Sinielnikowa-Muryliewa, Grebienkina, 2020). Jednak w drugiej połowie $2018 \mathrm{r}$. sytuacja się zmieniła i inflacja przyspieszyła. Można uznać, że było to konsekwencją zwiększenia stawki podatku VAT z 18 do 20\% (Filipina, Tołmaczew, 2019). Wskutek zagranicznych sankcji uległa osłabieniu siła nabywcza rubla. Pogorszyła się koniunktura wewnętrzna, umacniały pesymistyczne nastroje społeczne, co w rezultacie skutkowało w drugiej połowie $2018 \mathrm{r}$. wzrostem inflacji do 4,3\% wobec 2,7\% w roku poprzednim. Bank Rosji w ostatnim czasie kontynuował łagodną politykę pieniężną. Na koniec 2019 r. stopa podstawowa wynosiła 6,25\%. Oprocentowanie kredytu w walucie krajowej wynosiło średnio 8,3\% i było niższe niż przed rokiem o 1,3\%. Masa 
pieniężna M2 zwiększyła się w 2019 r. o 9,7\%. Rosło zaufanie do waluty krajowej. Wartość depozytów osób fizycznych zwiększyła się o 10,4\%, zmniejszała się natomiast wartość depozytów w walutach obcych wskutek wzmocnienia siły rubla (Stiepanczenko, 2019). Zwiększały się rezerwy walutowe Banku Rosji z 468,5 mld dolarów w 2018 r. do 554,4 mld dolarów w 2019 r. (Mieżdunarodnyje riezierwy, 2020). Wartość rezerw pozwalała finansować import w okresie 19 miesięcy. Poprawiała się sytuacja finansowa banków. Jeżeli w 2018 r. 79\% organizacji kredytowych generowało zyski, to na 1 stycznia 2020 r. takich jednostek było już 84\%. Zysk netto banków zwiększył się z 1,0 do 1,7 bln rubli. Banki posiadały 1,8 bln rubli kapitałów własnych. Poprawiła się też rentowność banków - z 12,2\% w 2018 r. do 16,6\% w 2019 r. (Mamownikow, Korżeniewskij, Karmanow, CberDannye, 2020).

Rok 2020 (rok zdominowany przez pandemię wirusa) przyniósł niekorzystne wyniki w gospodarce. Według Ministerstwa Rozwoju Gospodarczego Rosji w czerwcu 2020 r. PKB zmniejszył się o 6,4\% - rok do roku - wobec 10,7\% analogicznie w maju i 12,0\% w kwietniu. Według Banku Rosji w pierwszym półroczu zanotowano spadek PKB o 9-10\% (Nabiullina, 2020). W sumie spadek PKB w II kwartale 2020 r. szacowany jest na 9,6\% (Ministierstwo Ekonimiczieskowo, 2020b). Produkcja przemysłowa w kwietniu 2020 r. spadła o 6,6\%. Dwucyfrowe tempo spadku w kwietniu wykazała produkcja maszynowa, metalurgia, przemysł lekki, budownictwo, materiały i inne produkty mineralne (Ministierstwo Ekonomiczieskowo, 2020c). Lockdown gospodarczy stał się czynnikiem gwałtownie redukującym wielkość produkcji, wartość handlu i usług. Spadał popyt wewnętrzny, a w jeszcze większym tempie popyt zewnętrzny na rosyjskie towary i usługi. W sektorze kompleksu paliwowo-energetycznego odnotowano spadek produkcji pod wpływem słabnącego popytu zewnętrznego i zmniejszenia zużycia energii w Rosji z racji wprowadzanych ograniczeń i kwarantanny. Produkcja gazu ziemnego w kwietniu 2020 r. spadła o 9,7\% rok do roku, wydobycie węgla zmniejszyło się analogicznie o 6,9\% (Ministierstwo Ekonomiczieskowo 2020d). Za spadek PKB w zasadniczym stopniu odpowiadała sytuacja w sektorze wydobywczym i powiązanych $\mathrm{z}$ nim branżach - w maju i czerwcu załamanie wzrostu osiągnęło odpowiednio: -13,5\% oraz -14,2\%. Międzynarodowy Fundusz Walutowy obniżył prognozę dla rosyjskiej gospodarki na 2020 r. - szacował, że PKB spadnie o 6,6\%. Spowolnienie gospodarcze w Rosji tłumaczyć należy kryzysem wywołanym pandemią koronawirusa, a także spadkiem oczekiwanych wpływów z ropy naftowej na skutek załamania cen na rynkach światowych (Bank Rossii, 2020a). 


\section{Sytuacja w sektorze bankowym w Rosji}

Podobnie jak w większości krajów świata Bank Rosji odpowiada za zapewnienie stabilności finansowej i bezpieczeństwa sektora bankowego. Ta odpowiedzialność jest zdefiniowana w paragrafie 3 ustawy federalnej $O$ centralnom bankie Fiedieracii Rossii (Bankie Rosii) (Zakon, 2002). Zgodnie z tym celem Banku Rosji jest ochrona siły nabywczej rubla, rozwój i wzmocnienie systemu bankowego Federacji Rosyjskiej, zapewnienie stabilności i rozwoju krajowego systemu płatniczego, rozwój i bezpieczeństwo rynku finansowego (Afanasiewa, Dubowa, 2016). Kierownictwo Banku Rosji deklaruje potrzebę zmian zmierzających do naprawy i stabilizowania sektora banków komercyjnych. Podejmuje działania, które mają wzmocnić ten sektor (Matieriały, 2020). Działania te zmierzają do eliminowania z rynku instytucji finansowych niespełniających odpowiednich wymagań formalnych lub dysponujących niedostatecznym kapitałem dla bezpiecznego prowadzenia operacji finansowych. Na przestrzeni ostatnich lat systematycznie zmniejsza się liczba organizacji kredytowych. Dzieje się tak wskutek eliminowania z rynku instytucji pracujących nieefektywnie, nieprzestrzegających regulacji czy naruszających prawo bankowe (Fiedieralnyj, 1990).

Tabela 1. Liczba organizacji kredytowych w Rosji

\begin{tabular}{|l|c|c|c|}
\cline { 2 - 4 } \multicolumn{1}{l|}{} & 01.01 .2018 & 01.01 .2019 & 01.01 .2020 \\
\hline $\begin{array}{l}\text { Organizacje kredytowe zarejestrowane przez } \\
\text { Bank Rosji }\end{array}$ & 923 & 881 & 843 \\
\hline $\begin{array}{l}\text { Organizacje kredytowe mające prawo realizacji } \\
\text { operacji bankowych, z tego: }\end{array}$ & 561 & 484 & 454 \\
Banki & 517 & 440 & 414 \\
- z uniwersalną licencją & - & 291 & 273 \\
- z bazową licencją & - & 149 & 141 \\
- niebankowe organizacje kredytowe & 44 & 44 & 40 \\
\hline Organizacje kredytowe, którym została odebra- & 54 & 67 & 22 \\
na licencja na realizację operacji bankowych & 9 & 10 & 9 \\
\hline Organizacje kredytowe w procesie naprawczym & & & \\
\hline
\end{tabular}

Źródło: Chandrujew, A., Jepifanowa, J. (2020); Bank Rossii (2020a).

W 2000 r. w Rosji było zarejestrowanych 2378 organizacji kredytowych, w 2010 r. było ich już 1058, a w 2019 r. - 843. W 2018 r. pojawiła się nowa kategoria banków, których głównym przedmiotem obsługi jest sektor małych i średnich przedsiębiorstw. Na początku 2019 r. funkcjonowało 149 takich banków. 
Bank Rosji od wielu lat redukuje sektor bankowy, eliminując jednostki nieefektywne, naruszające prawo i łamiące obowiązujące procedury. Jeżeli w $2000 \mathrm{r}$. cofnięto licencję na prowadzenie operacji bankowych dla 1028 organizacji kredytowych, to w 2010 r. było takich przypadków 54, a w 2019 r. wyeliminowano kolejne 22 jednostki. Wprawdzie udział likwidowanych banków w aktywach sektora bankowego jest niewielki, kształtuje się na poziomie ok. 1\%, to jednak z punktu widzenia stabilności sektora jest to uzasadnione działanie (Novoselova, Miroshnikova, 2015). W postępowaniu likwidacyjnym banku przyjęto likwidację dobrowolną, przymusową (decyzja sądu administracyjnego) i upadłość, którą proceduje komisarz masy upadłościowej. Na początku 2020 r. według Banku Rosji 3 organizacje kredytowe procedowały dobrowolną likwidację, 33 były likwidowane przymusowo i 349 objęto postępowaniem upadłościowym (Komunikat Banka Rossii, b.d.). Pomimo niewielkiego udziału banków restrukturyzowanych w kapitałach banków ogółem, liczna ich grupa funkcjonuje nadal na rynku. Uzasadnia to krytyczną ocenę procesu restrukturyzacji organizacji kredytowych prowadzonego przez Bank Rosji. Od ponad dwudziestu lat trwa proces czyszczenia sektora bankowego, który do dziś nie został zakończony. Niewystarczający jest poziom profesjonalizmu i standardów etycznych kadry kierowniczej w wybranych bankach (Pojmanowa, 2018). Zdarzały się przypadki świadomego angażowania się kadry kierowniczej banków w operacje niezgodne z prawem, sprzeczne z interesami klientów i akcjonariuszy banków, obarczone nadmiernym ryzykiem (Skobielkin, 2019).

Decyzje podejmowane przez nadzór bankowy w Rosji, funkcjonujący w strukturach Banku Rosji, nie doprowadziły do zamierzonych efektów. Do 2020 r. nie wdrożono jednolitych standardów obowiązujących wszystkie kontrolowane banki (Igoriewna, 2017). Nadal preferowane są jednostki z dominującym udziałem kapitału państwowego. Zostały one wyposażone przez państwo w odpowiednie kapitały własne i obsługują największe korporacje, z dominującym udziałem własności państwowej. W niektórych przypadkach podporządkowano działalność banków celom politycznym. Instytucje państwowe wykorzystywały środki finansowe banków do realizacji partyjnych celów politycznych. Działania takie były podejmowane w bankach, $w$ których dominujący udział kapitałowy posiada państwo. Dla przykładu były to następujące banki: Sbierbank - 52,32\%, Rossielchozbank - 100\%, Chanti-Mansijskij Bank - 51\% Globeks - 99\%, MSP Bank 100\%, Rossijskij Kapitał Bank - 100\%, Wsierossijskij Bank Razwitija Regionow 84,67\% czy Poczta Bank - 50\% (Yandex, 2020b). 
92 | Przegląd Prawno-Ekonomiczny

Tabela 2. Wskaźniki sektora bankowego Rosji w latach 2016-2020

\begin{tabular}{|l|c|c|c|c|c|}
\hline \multicolumn{1}{|c|}{ Wskaźnik } & 2016 & 2017 & 2018 & 2019 & 2020 \\
\hline $\begin{array}{l}\text { Aktywa systemu bankowego, } \\
\text { miliardy rubli } \\
\text { w\% PKB }\end{array}$ & 82999,7 & 80063,3 & 85191,8 & 94084 & 96581,1 \\
\hline $\begin{array}{l}\text { Fundusze własne (kapitał), } \\
\text { miliardy rubli }\end{array}$ & 9008,6 & 9387,1 & 9397,3 & 10269,3 & 10981,1 \\
\hline w \% PKB & 10,8 & 10,9 & 10,2 & 9,9 & 10,0 \\
\hline $\begin{array}{l}\text { w \% aktywów sektora banko- } \\
\text { wego }\end{array}$ & 10,9 & 11,7 & 11,0 & 10,9 & 11,4 \\
\hline $\begin{array}{l}\text { Kredyty udzielone organiza- } \\
\text { cjom niefinansowym osobom } \\
\text { fizycznym, miliardy rubli }\end{array}$ & 43935,2 & 40938,6 & 42366,2 & 48273,2 & 51427,3 \\
\hline $\begin{array}{l}\text { Z tego: kredyty udzielone orga- } \\
\text { nizacjom niefinansowym } \\
\text { Osobom fizycznym }\end{array}$ & 33300,9 & 30134,7 & 30192,5 & 33371,8 & 33776,6 \\
\hline PKB, miliardy rubli & 83087,4 & 85616,1 & 91843,2 & 104629,6 & 110046,1 \\
\hline
\end{tabular}

Obliczenia własne na podstawie: RosStat (2020a).

Analizując wskaźniki osiągane w sektorze bankowym, można uznać, że na przestrzeni ostatnich lat wzrasta pozycja tego sektora w gospodarce (Ławruszin, Afansiewa, 2015). Jeżeli w 2000 r. relacja aktywów sektora bankowego do PKB wynosiła 32,6\%, to w 2019 r. było to już 87,8\% (VnieshEkonomBank, 2020). W przypadku Polski wskaźnik ten sięgał 124\%, dla Czech wskaźnik ten wynosił w 2018 r. 175,3\%, dla Węgier - 124,2\% oraz dla strefy euro - 475,7\% (NBP, 2020). Tylko w 2019 r. łączne aktywa sektora bankowego wzrosły z 94 do 96 bln rubli. Stało się tak ze względu na wzrost wartości zarówno aktywów rublowych, jak i aktywów w walucie obcej (Obzor finansowoj, 2019a). Dominujący udział w aktywach sektora bankowego (59,5\%) przypada na banki kontrolowane przez państwo. Udział kapitału zagranicznego w łącznej wartości kapitału funkcjonujących w Rosji organizacji kredytowych ustabilizował się na poziomie 12,4\%. Świadczy to o determinacji, by nie dopuszczać kapitału zagranicznego na rynek rosyjski, potwierdza też skuteczność polityki sankcji krajów zachodnich wobec Rosji (Obzor finansowoj, 2019b). Oznacza to też znaczący udział administracji państwowej w sterowaniu sektorem bankowym. Rynkowy mechanizm ma więc charakter w pewnym stopniu regulowanego administracyjnie. Miały miejsce również niekorzystne zjawiska w sektorze. Zbyt wolno zmieniała się relacja aktywów sektora bankowego do PKB w Rosji. Obniżano wartość aktywów poszczególnych banków, lokując je w papierach wartościowych (rublowych i walutowych). Utrata 
płynności oraz generowane straty w wyniku nietrafionych decyzji inwestycyjnych prowadziły w rezultacie do spadku realnej wartości kapitału sektora bankowego.

Kapitały sektora bankowego zwiększyły się w 2018 r. o 9,8\%, sięgając poziomu 10,3 bln rubli. Jeżeli chodzi o bazę zasobów finansowych organizacji kredytowych, to udział depozytów i funduszy organizacji w strukturze pasywów sięgał w $2018 \mathrm{r}$. 29,8\%. W relacji do PKB wskaźnik ten nie zmienił się i wynosił 27,0\%. Udział depozytów osób fizycznych w pasywach banków ustabilizował się na poziomie $30,2 \%$, a stosunek depozytów gospodarstw domowych do PKB wynosił $27,4 \%$ (Obzor finansowoj, 2019c). Niski poziom kapitalizacji sektora bankowego nie pozwalał na zaawansowane kredytowanie podmiotów rosyjskiej gospodarki (Larionova, 2013).

Do 2018 r. utrzymywała się stabilna tendencja w segmencie kredytów, której sprzyjał rosnący popyt inwestycyjny i konsumpcyjny w gospodarce. Portfel kredytów dla organizacji niefinansowych i osób fizycznych w 2018 r. wzrósł o 10,7\% i osiągnął wartość 48,3 bln rubli. Udział kredytów w aktywach banków wzrósł z 49,7 do 51,3\%. Zadłużenie organizacji niefinansowych w bankach zwiększyło się o 5,8\% i osiągnęło wartość 33,4 bln rubli (Assocjacija, 2020). W bankach komercyjnych jednak nadmiernie koncentrowano się na operacjach przynoszących w krótkim czasie duży zysk, jak np. spekulacyjnych operacjach walutowych czy operacjach z papierami wartościowymi lub sprzedażą kredytów hipotecznych bez odpowiedniego zabezpieczenia. Operacje te polegały na oferowaniu nabywcy produktów obarczonych wysokim ryzykiem na warunkach obarczenia klienta skutkami tego ryzyka. W wyniku prowadzonej polityki kredytowej na wysokim poziomie kształtował się wskaźnik przeterminowanych kredytów, co prowadziło do spadku realnej wartości aktywów banków (Biuro Krieditnych, 2019). Kredytowano na preferencyjnych warunkach wybranych akcjonariuszy kosztem pozostałych klientów. Podejmowano decyzje odpowiadające interesom większościowych akcjonariuszy, będących jednocześnie członkami powiązanych kapitałowo czy personalnie grup finansowo-przemysłowych. W wielu przypadkach prowadziło to do realizacji operacji finansowych, preferujących interesy wybranych klientów.

Wzrastał zysk brutto sektora bankowego. Jeżeli w 2017 r. wypracowano 789,7 mld rubli, to w 2018 r. 1,345 bln rubli, a w 2019 r. już 2,036 bln rubli zysku brutto. Główny wkład w wypracowaniu dodatniego wyniku finansowego wniosły banki kontrolowane przez państwo - 1,4 bln rubli, oraz banki z kapitałem zagranicznym - 279 mld rubli, a także duże i średnie banki prywatne - 137 mld rubli. Banki poddawane procedurze restrukturyzacji wygenerowały w $2018 \mathrm{r}$. ujemny wynik, głównie z powodu narzuconego im obowiązku stworzenia rezerw 
na potencjalne straty za 2018 r. (Obszczije, 2020). Zwrot na aktywach (ROA) organizacji kredytowych w 2018 r. wyniósł 1,5\%, a rentowność kapitału ROE 13,3\%. W 2017 r. było znacznie gorzej: odpowiednio 1,0\% oraz 8,3\%. Najbardziej rentowne w 2018 r. były banki kontrolowane przez państwo, które uzyskały: ROA - 2,6\%, ROE - 19,6\%, a także banki kontrolowane przez nierezydentów ze wskaźnikami odpowiednio 2,8 i 18,0\% (Likwidnost, 2018). Najważniejszym źródłem generującym wyniki finansowe w 2018 r. dla wszystkich grup banków był dochód procentowy netto. Jego udział w strukturze zysku ogółem wyniósł 67\%, zamykając się kwotą 3,1 bln rubli. Największą część - ok. 67\% - wypracowały banki kontrolowane przez państwo.

Tabela 3. Struktura zysku i kosztów w sektorze bankowym w Rosji

\begin{tabular}{|l|c|c|c|c|}
\cline { 2 - 5 } \multicolumn{1}{c|}{} & $\begin{array}{c}2017 \mathrm{r} . \\
\text { mld rubli }\end{array}$ & $\begin{array}{c}2018 \mathrm{r} . \\
\text { mld rubli }\end{array}$ & $\begin{array}{c}\text { Dynamika } \\
\text { mld rubli }\end{array}$ & $\begin{array}{c}\text { Dynamika } \\
\%\end{array}$ \\
\hline Dochód odsetkowy & 2593 & 3079 & 486 & 18,7 \\
\hline Z operacji na papierach wartościowych & 258 & 226 & -33 & $-12,7$ \\
\hline $\begin{array}{l}\text { Z operacji walutowych i cennymi } \\
\text { metalami }\end{array}$ & 92 & 157 & 65 & 70,2 \\
\hline Prowizje & 926 & 1125 & 199 & 21,5 \\
\hline Inne dochody & 170 & 10 & -161 & $-94,3$ \\
\hline Koszty działalności bankowej & 1821 & 2044 & 223 & 12,3 \\
\hline Koszty rezerw & 1433 & 1206 & -227 & $-15,8$ \\
\hline Zysk brutto & 785 & 1345 & 560 & 71,3 \\
\hline
\end{tabular}

Źródło: opracowanie własne na podstawie: Bank Rosii Likwidnost bankowskowo siektora i finansowyje rynki. Fakty, ocenki, kommentarii (2018). (s. 3-9). Moskwa. Pobrano z: https://zen.yandex.ru/media/ id/5c34c677cffc6400aaed02c4/rossiiskie-banki-finansovye-itogi-2019-goda-5e447debd877b06d5336c965 (23.07.2020); Bratkowa, L.G. (2017). Ekonomiczieskij analiz diejatielnosti kommierczieskowo banka (s. 34-56). Moskwa.

Dynamika wskaźników wypracowanych w sektorze bankowym w Rosji na przestrzeni ostatnich lat do 2020 r. świadczy jednak o dążeniu władz państwowych do jego stabilizacji. Umożliwiało to płynne finansowanie gospodarki, poprawiało bezpieczeństwo i efektywność pracy banków komercyjnych. Działo się tak w środowisku spadających stóp procentowych banku centralnego, obniżania oprocentowania kredytów bankowych, rosnącej konsumpcji dóbr powszechnego użytku i inwestycji. Poprawiała się wiarygodność kredytowa klientów indywidualnych i korporacyjnych.

Globalne rozprzestrzenianie się COVID-19 uderzyło jednak w 2020 r. w rosyjską gospodarkę i sektor finansowy. Stało się tak zarówno poprzez pogorszenie 
zewnętrznych warunków ekonomicznych, jak i w wyniku wprowadzenia środków restrykcyjnych, w tym wpływających na zmniejszenie krajowej produkcji towarów i usług. W okresie od kwietnia do czerwca straty w gospodarce narodowej wyniosły $18 \%$, a dochody ludności zostały zredukowane o $17 \%$. Przewidywano, że gospodarka rosyjska w 2020 r. zmniejszy się o 3,8\%, realne dochody do dyspozycji spadną o 6,5\%, (Zubkow, 2020). Według danych Rosstatu (odpowiednik GUS) obroty gospodarki spadły z 4 do 3 bln rubli. Przy optymistycznej prognozie makroekonomicznej w 2021 r. Rosja będzie w stanie odrobić straty z 2020 r. Stanie się to możliwe, jeśli rząd wdroży pakiet działań, które pozwolą wesprzeć i wyprowadzić z kryzysu małe i średnie przedsiębiorstwa (Turdyjewa, 2020). Szacuje się, że pod koniec 2020 r. powinien wzrosnąć portfel kredytowy osób fizycznych i przedsiębiorstw. Bank centralny zgromadził w tym celu 600 mld rubli na zabezpieczenie ryzyka kredytowego banków komercyjnych. W 2021 r. przewiduje się spadek inflacji poniżej 4\%. Rada Dyrektorów Banku Rosji z tego powodu obniżyła w lipcu $2020 \mathrm{r}$. stopy procentowe do 4,25\%, co powinno zasilić rynek bankowy tanim pieniądzem, łatwiej dostępnym dla gospodarki i ludności (Nabiullina, 2020).

Biorąc pod uwagę czynniki zewnętrzne i wewnętrzne, można wyróżnić cztery kanały transmisji wstrząsów, jakie wywołała epidemia koronawirusa w sektorze finansowym w Rosji (Obzor finansowoj, 2020a).

\subsection{Kanat bilansu ptatniczego}

Spowolnienie wzrostu gospodarczego na świecie doprowadziło do gwałtownego pogorszenia warunków handlu zagranicznego. Miało to niekorzystny wpływ na gospodarkę rosyjską, silnie uzależnioną od poziomu cen i wolumenu popytu na surowce energetyczne, których znaczącym eksporterem jest Rosja. Rosyjska gospodarka stanęła w obliczu bezprecedensowego pogorszenia sytuacji na rynkach surowcowych wskutek istotnego spadku cen nośników energetycznych. Zanotowano duży odpływ środków nierezydentów z rosyjskiego rynku papierów wartościowych. Na rynku zaobserwowano rekordowy w ciągu ostatnich 30 lat spadek cen ropy naftowej Brent i Urals - głównej marki rosyjskiego eksportu. Jeśli w poprzednich latach było to średnio 2-3 dolary, to na początku kwietnia 2020 r. spadek cen przekroczył 15 dolarów. Rekordowo niski poziom odnotowano 21 kwietnia 2020 r., kiedy to baryłka ropy marki Urals kosztowała na rynku 8,4 dolara, czyli o 87\% mniej niż na początku 2020 r. (Obzor finansowoj, 2020b).

Zgodnie z zawartą w kwietniu 2020 r. umową z krajami produkującymi ropę naftową Rosja zadeklarowała zmniejszenie wydobycia ropy o ok. 20\%. Nowe po- 
rozumienie miało na celu stworzenie w średnim okresie warunków do osiągnięcia równowagi na rynku ropy naftowej, a tym samym do przywrócenia cen. Jednak w krótkim czasie przyniosło to spadek przychodów z eksportu ropy naftowej.

Według danych Banku Rosji nadwyżka na rachunku obrotów bieżących bilansu płatniczego w I kwartale 2020 r. - w stosunku do analogicznego kwartału poprzedniego roku - zmniejszyła się o ponad jedną trzecią - z 33,6 do 21,7 mld dolarów (Płatieżnyj Bałans, 2020). Niekorzystna była też sytuacja na rynku gazu. W pierwszym kwartale $2020 \mathrm{r}$. zmniejszył się eksport tego surowca z racji nagromadzenia w Europie jego rekordowych zapasów, po ciepłej zimie i zwiększonych dostawach LNG. Instrumentem w stabilizowaniu równowagi wewnętrznej stała się zwiększona sprzedaż waluty obcej przez Bank Rosji, co złagodziło skutki niekorzystnych zmian na rachunku bieżącego bilansu. W wyniku pogarszających się perspektyw rozwoju gospodarki ponownie pojawiło się ryzyko inwestycyjne na rynku instrumentów finansowych. Presja sprzedażowa nierezydentów, a także zmiany nastawienia na ryzyko lokalnych graczy zachwiały tym rynkiem. W I kwartale $2020 \mathrm{r}$. z rosyjskiego rynku papierów wartościowych odpłynęło 12,1 mld dolarów (Obzor finansowoj, 2020c). Zgodnie z regułą budżetową Bank Rosji rozpoczął w II kwartale 2020 r. sprzedaż walut obcych, co pozwoliło w pewnym stopniu złagodzić bilans płatniczy rachunku bieżącego.

\subsection{Kanał cen aktywów finansowych}

W obliczu pandemii koronawirusa i pogarszających się perspektyw rozwoju gospodarczego w Rosji dokonano w drugim kwartale 2020 r. weryfikacji poziomu ryzyka i wyceny wartości instrumentów finansowych. Aktywność nierezydentów sprzedających papiery, a także zmiana zachowania lokalnych graczy zaburzyły równowagę na rynku. Pierwszoplanowym zadaniem Banku Rosji stało się utrzymanie stabilnych cen. Stabilizacja oczekiwań inflacyjnych uczestników rynku uzasadniła bankowi centralnemu prowadzenie łagodnego kursu polityki pieniężnej, argumentując podjęte działania przewidywaniem krótkoterminowego szoku inflacyjnego. Pozwoliło to ograniczyć potencjalny wpływ pandemii koronawirusa na gospodarkę poprzez dyscyplinowanie kosztów. Przede wszystkim umożliwiło zasilenie gospodarki względnie tanim pieniądzem, co z kolei skutkowało relatywnie niskimi cenami kredytów. Dla celów praktycznych w Rosji zastosowano metodę pozwalającą na prezentację scenariuszy warunków skrajnych i oceny prawdopodobieństwa ich realizacji. Została ona wykorzystana dla dokonania oceny wpływu potencjalnych zagrożeń stabilności finansowej i wpływu polityki makroostrożnościowej na sektor realny (Aikman, Bridges, Hacioglu Hoke, 
Neill, Raja, 2019). Bank Rosji, równolegle z czynnościami podjętymi przez inne centralne banki, zmerzał do ustabilizowania sytuacji na rynkach finansowych. Chodziło też o ograniczenie ryzyka, pozwalającego uniknąć potencjalnych strat, jakie pojawiłyby się na zdestabilizowanych rynkach finansowych.

\subsection{Kanat dochodowy}

Pandemia COVID-19 spowodowała wprowadzenie lockdownu w gospodarce rosyjskiej - wstrzymano lub ograniczono produkcjęi usługi. Wpłynęło to negatywnie na dochody wszystkich gałęzi gospodarki; sektora przedsiębiorstw niefinansowych, sektora finansowego i w konsekwencji pracowników. Został zachwiany łańcuch dostaw, a w wyniku tego przepływy finansowe interesariuszy: przedsiębiorstwo, kontrahenci, dostawcy, odbiorcy, właściciele i zatrudnieni pracownicy. Zmniejszenie dochodów odnotował też budżet państwa. Jak podaje Ministerstwo Finansów Federacji Rosji, deficyt budżetu federalnego w 2020 r. wyniesie ok. 4\% PKB. W tym miejscu należy podkreślić, że dług publiczny Federacji Rosyjskiej jest relatywnie nieduży. Dług zagraniczny to $54848,3 \mathrm{mln}$ dolarów, z tego gwarantowany przez państwo - 13 252,8 mln dolarów (Ministierstwo Finansow, 2020a). Wartość długu krajowego Federacji Rosyjskiej na początku 2020 r. wynosiła 10 171,9 mld rubli, do 1 lipca 2020 r. zwiększyła się do 11 171,1 mld rubli (Ministierstwo Finansow, 2020b). Zauważyć należy, że zadłużenie łączne (zewnętrzne i wewnętrzne) w relacji do PKB wyniosło w 2020 r. ok. 16,5\% (Czałowa, 2019). Tak niski poziom długu daje duży potencjał do bezpiecznego finansowania deficytu budżetowego poprzez rynek obligacji skarbowych. Sytuacja na poziomie makroekonomicznym w Rosji jest więc korzystna. Natomiast trudniejsza jest sytuacja w gospodarstwach domowych. Odczują one spadek dochodów z racji ograniczenia świadczonej pracy. W efekcie gospodarka rosyjska w $2020 \mathrm{r}$. zmniejszy się - według prognoz sformułowanych w kwietniu 2020 r. - o 3,8\%, realne dochody do dyspozycji - o 6,5\% (Ministierstwo Finansow, 2020c). W lipcu 2020 r. skorygowano spadek PKB do 9-10\%. W szczególnie niekorzystnej sytuacji znajdują się klienci banków spłacający raty kredytowe. To z kolei powoduje zmniejszenie zdolności kredytowej i ogranicza aktywność banków komercyjnych.

\subsection{Kanat kredytowy}

Kanałem negatywnego wpływu pandemii może być zmniejszenie aktywności sektora finansowego, zwłaszcza działalności pożyczkowej. Spadek dochodów podmiotów gospodarczych pogarsza ich zdolność kredytową, co z kolei zmniej- 
sza skłonność banków do dalszego kredytowania gospodarki. Wpływ pandemii za pośrednictwem kanału kredytowego wyraża się poprzez synergię następujących ryzyk:

- banki zaostrzają kryteria wymaganej zdolności kredytowej w związku z pogorszeniem sytuacji finansowej klientów, chcąc ograniczać ryzyko pogorszenia jakości portfela kredytowego;

- zmniejszone dochody potencjalnych kredytobiorców hamują ich skłonność do sięgania po środki udostępniane przez banki ze względu na ograniczone możliwości spłaty rat pożyczek;

- istnieje niepewność co do przywrócenia w najbliższej przyszłości dotychczasowych dochodów obywateli i przedsiębiorstw;

- pogorszenie zdolności kredytowej kredytobiorców oraz wzrost ryzyka kredytowego skłaniają banki do wzrostu oprocentowania kredytów, co w rezultacie ogranicza popyt na nowe kredyty;

- przeszkodą w uzyskaniu kredytu jest ograniczanie mobilności obywateli, co ma znaczenie dla tych osób, które nie korzystają z kanałów bankowości zdalnej;

- $\quad$ w warunkach pogarszającej się sytuacji finansowej niektóre banki mogą stanąć w obliczu braku kapitału niezbędnego do prowadzenia akcji kredytowej.

Wymienione czynniki generują uzasadnienie dla zaostrzenia wymagań ostrożnościowych przez banki. To z kolei może stać się czynnikiem pogorszenia koniunktury, ponieważ ograniczenie dostępu do finansowania zewnętrznego utrudni podmiotom gospodarczym utrzymanie dotychczasowego poziomu działalności produkcyjnej czy usługowej. W rezultacie występuje sprzężenie zwrotne: obniżenie aktywności gospodarczej powoduje spadek akcji kredytowej, co z kolei hamuje słabnącą aktywność gospodarczą. Analizując znaczenie efektu sprzężenia zwrotnego, Bank Rosji przeprowadził badania mające na celu ukazanie współzależności pomiędzy dynamiką PKB a aktywnością kredytową w sektorze bankowym. Uzyskane wyniki potwierdzają, że pogorszeniu się otoczenia makroekonomicznego towarzyszy spadek wolumenu udzielonych kredytów, co w konsekwencji prowadzi do dalszego obniżenia aktywności gospodarczej o ok. 40\% w stosunku do poziomu, który zostałby osiągnięty bez efektu sprzężenia zwrotnego (Obzor finansowoj, 2020d). W literaturze ekonomicznej efekt ten nazywany jest „efektem drugiej rundy” (second-round effects - SRE) lub „efektem sprzężenia zwrotnego" (macroeconomic feedback loop effects). Ocena SRE była wielokrotnie prezentowana w materiałach makroostrożnościowych stress-testów sektora bankowego, w tym banków centralnych EBC i Banku Japonii (Kitamura, 2014). 


\section{Wpływ SARS CoV-2 na sektor bankowy w Rosji}

Rosyjski sektor bankowy znalazł się ostatnio dwa razy w sytuacjach kryzysowych. W latach 2008-2009, kiedy wiele krajów na całym świecie zmagało się z perturbacjami systemu finansowego. Po kilku latach sytuacja została opanowana i sektor bankowy się ustabilizował. Jednak w latach 2014-2015 pojawiły się nowe okoliczności polityczne i ekonomiczne, które zachwiały osiągniętą stabilność. Stało się tak wskutek wprowadzenia wobec Rosji sankcji przez USA, Kanadę i Unię Europejską. Rosja została pozbawiona dostępu do taniego i długookresowego kredytu zagranicznego. Bank Rosji nie miał możliwości kredytowania całego sektora komercyjnego. Spadło społeczne zaufanie do banków wskutek masowego likwidowania nieefektywnych jednostek. Ludność nie powierzała oszczędności instytucjom kredytowym, co w konsekwencji skutkowało zmniejszeniem bazy depozytowej banków i ograniczeniem możliwości finansowania gospodarki. W 2014 r. nastąpił poważny wstrząs makroekonomiczny - deprecjacja rubla rosyjskiego. W okresie stagnacji w realnym sektorze gospodarki zagraniczni inwestorzy przestali inwestować nie tylko w produkcję, lecz także w rosyjskie banki (Byczkow, Podlinnykh, 2015). Po kilku latach sektor banków komercyjnych jednak się wzmocnił. Na początku 2020 r. był już bardziej niż przed kilkoma latami odporny na turbulencje (Połbin, Sinielnikow-Muryliew, Trunin, 2020), w przeciwieństwie do realnego sektora gospodarki, który jest bardziej wrażliwy na zawirowania na rynkach światowych i potrzebuje dodatkowych środków finansowych. Pomimo negatywnego wpływu koronawirusa na stabilność finansową firm segment kredytów korporacyjnych na początku 2020 r. rósł, zanotowano 3\% wzrost zadłużenia przedsiębiorstw. Sprzyjały temu m.in. narzędzia wspierania pożyczek uruchomione przez bank centralny i rząd Rosji. Bank Rosji w tym celu zawiesił wymóg tworzenia rezerw obowiązkowych dla organizacji kredytowych do 30 września 2020 r., zapowiadając ewentualne przedłużenie zawieszenia. Pozwoliło to zmniejszyć obciążenia banków i zabezpieczyć środki na rzecz finansowania osłabionej gospodarki. Z powodu pogorszenia sytuacji finansowej zatrudnionych zmniejszyła się natomiast dynamika zadłużenia osób fizycznych. Dzieje się tak z racji pogorszenia zdolności kredytowej, jak również wskutek zaostrzania przez banki wymagań w zakresie zabezpieczenia zdolności kredytowej klientów. Również ograniczenia w swobodnym przemieszczaniu się zmniejszyły możliwości klientów korzystających z tradycyjnych form procedowania operacji bankowych, a tym samym skutkowały zmniejszeniem popytu na kredyty. 
Bank Rosji już w kwietniu uruchomił linie kredytowe dla uzupełnienia zasobów banków komercyjnych w celu podtrzymania dynamiki wzrostu portfela kredytów hipotecznych. Przyznał też bankom komercyjnym prawo do odroczenia do 30 marca 2021 r. obowiązku zawiązywania rezerw na wszystkie kredyty restrukturyzowane w związku z rozprzestrzenianiem się koronawirusa. Poprawia to ich sytuację finansową i umożliwia finansowanie kredytobiorców (Fiedieralnyj zakon, 2020).

W pierwszym półroczu 2020 r. stabilność banków komercyjnych utrzymywała się na bezpiecznym poziomie dzięki zgromadzonym w poprzednim czasie nadwyżkom kapitału. Mając jednak na uwadze potencjalne problemy w gospodarce, Bank Rosji podjął działania w kierunku poprawy dostępności kredytów w średniej i długoterminowej perspektywie. Zwiększono wartość operacji REPO na okres do 1 roku, zwiększono strumien środków oferowanych w ramach kredytu lombardowego, a również złagodzono regułę bieżącej płynności (Bazylea III) dedykowaną dla tzw. znaczących systemowo banków komercyjnych. Wraz z obniżeniem podstawowych stóp procentowych banku centralnego pojawiły się możliwości zmniejszenia marży banków uczestniczących w operacjach otwartego rynku, a tym samym niepowiększanie ceny kredytów. Pozwoliło to w konsekwencji sięgać po kredyty także tym klientom, których sytuacja finansowa pogorszyła się w ostatnim czasie. W drugim półroczu 2020 r. banki komercyjne zrestrukturyzowały pożyczki klientów korporacyjnych na sumę 1,2 bln rubli, co stanowiło 3,7\% portfela kredytowego banków. W ciągu ostatnich 4 lat udział kredytów walutowych w portfelu kredytów korporacyjnych spadł z 40 do 28\%. Jednak wkład komponentu walutowego jest nadal znaczący w bilansach wielu banków. Równocześnie osłabienie rubla prowadzi do znacznego wzrostu wartości aktywów ważonych ryzykiem i obniża wartość współczynnika wypłacalności. W związku z sytuacją pandemiczną Bank Rosji zezwolił instytucjom kredytowym na zawieranie transakcji w walutach wymienialnych w okresie 6 miesięcy przy przestrzeganiu obowiązkowych wskaźników efektywności i wartości kapitału po oficjalnym kursie wymiany walut w stosunku do rubla ustalonym przez Bank Rosji na dzień 1 marca 2020 r. Makroostrożnościowy bufor kapitałowy ma być zlikwidowany w przypadku znacznego wzrostu strat na portfelu kredytowym w walutach obcych lub w sytuacji, gdy banki będą zmuszone do znaczącej restrukturyzacji kredytów walutowych dla kredytobiorców mających trudności z obsługą zadłużenia walutowego. Zdaniem banku centralnego, nawet jeżeli marże zostaną zredukowane do zera, banki będą w stanie zaabsorbować straty bez zmiany bieżącej wartości współczynników wypłacalności. Bank Rosji zadeklarował, że do 30 września 2020 r. nie będzie egzekwował wymogów formal- 
nych w tych instytucjach kredytowych, które zamierzają przewalutować swoim klientom kredyty dewizowe na walutę krajową. Chodzi o takie firmy, które z racji epidemii znajdują się w trudnej sytuacji finansowej oraz wystąpią do banku o zmianę zasad spłaty rat i odsetek, a także przedstawią plan restrukturyzacji zadłużenia. W przypadku kredytów dla Małych i Średnich Przedsiębiorstw zrestrukturyzowano portfel o wartości 342,3 mld rubli, co stanowi 6,9\% wartości portfela kredytowego MŚP.

\section{Zakończenie}

Sytuacja makroekonomiczna na przestrzeni ostatnich kilku lat w Rosji nie jest korzystna. Składają się na to dwie okoliczności: niekorzystne skutki sankcji zagranicznych oraz gwałtowne i głębokie spadki cen surowców energetycznych, których znaczącym eksporterem jest Rosja. System bankowy już w pierwszych miesiącach 2020 r. zaczął odczuwać konsekwencje gwałtownie rozprzestrzeniającej się pandemii koronawirusa SARS-CoV-2. W Banku Rosji podjęto działania w dwóch strategicznych obszarach. Uznano za konieczne wsparcie sektora banków komercyjnych. Celem takiego działania była troska o stabilność banków i innych instytucji finansowych. Zmniejszono stopy procentowe banku centralnego, co pozwoliło zasilić sektor bankowy relatywnie tanim pieniądzem. Nadzór bankowy - ulokowany w strukturach banku centralnego - złagodził też wymagania formalne w odniesieniu do polityki kredytowej banków. Było to niezbędne, szczególnie z racji pogorszenia sytuacji finansowej klientów. Działania miały na celu łagodzenie skutków spowodowanych przez rosnące ryzyko kredytowe z tytułu pogorszenia zdolności kredytowej ludności, a także radykalnego ograniczenia w przemieszczaniu się ludności. Pozwoliło to zasilić rynek, pomogło klientom banków sprostać złagodzonym wymaganiom co do zdolności kredytowej. Spodziewając się wzrostu przeterminowanego zadłużenia, przyjęto plan restrukturyzacji pożyczek poprzez wprowadzenie 6-miesięcznych wakacji kredytowych tym pożyczkobiorcom, którzy znaleźli się w trudnej sytuacji finansowej. W rezultacie w okresie od 20 marca do 6 maja 2020 r. instytucje kredytowe przyjęły ponad 700 tys. wniosków o restrukturyzację kredytów, z czego 210 tys. na podstawie ustawy o wakacjach kredytowych (Obzor finansowoj, 2020e). Analizując informacje statystyczne związane z funkcjonowaniem i ewolucją sektora bankowego, można uznać, że istnieje potencjał dla łagodzenia w perspektywie średniej skutków kryzysu epidemii koronawirusa w Rosji. Zależy to jednak od wielu czynników występujących zarówno w gospodarce światowej, 
jak i wewnętrznej polityce gospodarczej Rosji oraz w charakterze i dynamice zmian umożliwiających stabilizowanie sektora bankowego.

\section{Bibliografia}

\section{Akty normatywne}

Fiedieralnyj zakon ot 02.12.1990 g. N 395-1 „O bankach i bankowskoj diejatielnosti”.

Fiedieralnyj zakon ot 10.07.2002, N 86-FZ. O cientralnom bankie Rossijskoj Fiedieracii (Bankie Rossii).

Fiedieralnyj Zakon ot 03.042020 N 106-FZ (2020). Fiedieralnyj zakon „O wniesienii izmienienij. W Fiedieralnyj zakon „O cientralnom bankie Rossijskoj Fiedieracii (Bankie Rossii).

\section{Publikacje Banku Rosji}

Bank Rossii (2018). Likwidnost bankowskowo siektora i finansowyje rynki. Ekonomika: Fakty, ocenki, kommentarii (s. 3-5). Moskwa.

Bank Rossii (2020a). Godowoj otcziot Banka Rossii za 2019 g. (s. 16-27). Pobrano z http:// www.cbr.ru/collection/collection/file/27873/ar_2019.pdf (17.06.2020).

Bank Rossii (2020b). Obszczije swiedienija o bankowskom siektorie. (tab. T. 24: Sektor bankowy w 2019 r.) (s. 24-25). Moskwa.

Informacionno analiticzieskij materiał. I kwartał 2020. (2020). Płatieżnyj bałans Rossii, 1(3), 6-9. Pobrano z https://cbr.ru/Collection/Collection/File/27812/Balance_of_ Payments_2020-01_3.pdf (09.08.2020).

Mieżdunarodnyje riezierwy Rossijskoj Fiedieracii (2020). Pobrano z https://cbr.ru/hd_base/ $\mathrm{mrrf} / \mathrm{mrrf} \_\mathrm{m} /(22.06 .2020)$.

Obszczije swiedienija o bankowskom siektorie. (2020). Moskwa Informacionno analiticzieskij materiał, nr 1 I kwartał (s. 2-19).

Obzor bankowskowo siektora Rossijskoj Fiedieracii. (2018). Statisticzieskije pokazatieli, tabl. 1 .

Obzor bankowskowo siektora Rossijskoj Fiedieracii. (2019). Statisticzieskije pokazatieli, tabl. 1 .

Obzor finansowoj stabilnosti. (2019a) Informacionno-analiticzieskij matieriał, IV kwartat 2019 -I kwartat 2020 g. (s. 12). Moskwa.

Obzor finansowoj stabilnosti. (2019b). Informacionno-analiticzieskij matieriał, IV kwartat 2019-I kwartał 2020 g. (s. 16). Moskwa.

Obzor finansowoj stabilnosti. (2019c). Informacionno-analiticzieskij matieriał, IV kwartat 2019-I kwartał 2020 g. (s. 19). Moskwa. 
Obzor finansowoj stabilnosti. (2020a). Informacionno-analiticzieskij materiał (s. 16-24). Moskwa.

Obzor finansowoj stabilnosti (2020b), Informacionno-analiticzieskij materiał, 1(16), 40. Obzor finansowoj stabilnosti. (2020c). Informacionno-analiticzieskij materiał, 1(16), 44. Obzor finansowoj stabilnosti. (2020d). Informacionno-analiticzieskij materiał, 1(16), 49. Obzor finansowoj stabilnosti. (2020e). Informacionno-analiticzieskij materiał, 1(16), 50.

\section{Literatura}

Afanasiewa, O., Dubowa, S. (2016). Makroekonomiczieskuj analiz bankowskoj sfiery. Moskwa: Finansowyj Uniwiersytiet pri Prawitielstwie Rossijskoj Fiedieracii.

Aikman, D., Bridges, J., Hacioglu Hoke, S., O’Neill, C., Raja, A. (2019). Credit, capital and crises: a GDP-at-Risk approach. Bank of England, Staff Working Paper, 824, 1-64.

Andrianow, W. (2015). Infliacija; pricziny wozniknowienija i mietody riegulirowanija. Moskwa.

Associacija Rossijskich Bankow. (2020). Informacionno analiticzieskoe obozrenije, Kreditowanije niefinansowowo siektora ekonomiki. Moskwa.

Biuro Krieditnych Istorij. (2019). Analiz tiendencij na rynkie krieditowanija fiziczieskich lic w 2015-2019 godach na osnowie danych. Moskwa.

Budanik, K. i in. (2019). Macroprudential stress test of the euro area banking system. Occasional Paper Series, 226, 48. Pobrano z https://www.ecb.europa.eu/pub/ pdf/scpops/ecb.op226 5e126a8e37.en.pdf?ealfa9245c4ba6874b042fd42620cl 5c (16.04.2020).

Byczkow, A., Podlinnykh, D. (2015). Rosijskii bankowyj siektor pod wlijanijem krizisa 2014-2015. Maładoj uczionnyj, 10(90), 548-551.

Chandrujew, A., Jepifanowa, J. (2020). Bankowskaja sistiema (s. 6-9). Moskwa: Associacija banków Rossii.

Czałowa, A. (2019). Gosudarstwiennyj dołg w stranach mira $i$ w Rossii. Probliema ili nieobchodimost. Moskwa: Holding Finam.

Dees, S., Henry, J. Martin, E. (red.). (2017). STAMP€: Stress-test analytics for macroprudential purposes in the euro area (s. 17-24). Pobrano z https://www.researchgate. net/publication/314179224_STAMP_Stress-Test_Analytics_for_Macroprudential_Purposes_in_the_euro_area\#read? (14.01.2020).

Departament Stabilności Finansowej NBP. (2020). Rozwój systemu finansowego w Polsce. Pobrano z https://www.nbp.pl/systemfinansowy/rozwoj2016_prezentacja.pdf (20.01.2020).

Filipina, F., Tołmaczew, I. (2019). Nałog na dobawliennuju stoimost. Moskwa: RosBuch. Igoriewna, I. (2017). Proporcii tradicionnoj diejatelnosti kommierczieskich banków. Wiestnik Finannsowowo Uniwiersytieta, 21(2), 52. 
Iwasienko, A., Nikonowa, J. (2020). Makroekonomika. Moskwa.

Kamiennikow, W. S. (2015). Mieżdunarodnoje regulirowanije wnieszekonomiczieskoj diejatielnosti. Moskwa: Izdatelstwo diełowoj i ucziebnoj litieratury.

Kitamura, T. i in. (2014). Macro stress testing at the Bank of Japan. BOJ Reports \& Research Papers. Pobrano z https://www.boj.or.jp/en/research/brp/ron_2014/data/ ron141008a.pdf (18.05.2020).

Komunikat Banka Rosii Krieditnaja organizacija u katoroi otozwana ili annulirowana licenzija na osuszczestwlienije bankowskich opieraciij, dołżna byt likwidirowana w sootwietstwii z zakonodatielstwom (b.d.). Pobrano z https://cbr.ru/banking_sector/likvidbase/ (22.07.2020).

Larionova, I. (2013). System risks of russian banking: valuation and regulation methods. Bulletin of Financjal University, 1(73), 28.

Ławruszin, I., Afansiewa, O. (2015). Bankowskoje dieło: sowriemiennaja sistiema kreditowanija. Moskwa: Finansowaja Akademija pri Prawitielstwie Rossijskoj Fiedieracii.

Mamownikow, M., Korżeniewskij, N., Karmanow, M. (2019). Sbierdannyie. Bankowskije itogi. Moskwa: Izdatielstwo Sbierbanka.

Matieriały Sowieta Razwitija Finansowowo Rynka z 13 lipca 2020 r. (2020). Pobrano z http://www.cbr.ru/press/event/?id=6914 (17.07.2020).

Ministierstwo Ekonomiczieskowo Razwitija. (2020a). Kliucziewyje naprawlienija diejatielnosti Minekonomrazwitija Rossii w sfierie makroekonomiki. Pobrano z: https://www.economy.gov.ru/material/directions/makroec/ (16.07.2020).

Ministierstwo Ekonomiczieskowo Razwitija. (2020b). Kliucziewyje naprawlienija diejatielnosti Minekonomrazwitija Rossii w sfierie makroekonomiki. Pobrano z https://www.economy.gov.ru/material/file/d80f613a522clbb9b96d7769303f7ace/200717_1.pdf (17.07.2020).

Ministierstwo Ekonomiczieskowo Razwitija. (2020c). Kliucziewyje naprawlienija diejatielnosti Minekonomrazwitija Rossii w sfierie makroekonomiki (s. 2). Pobrano z https://www.economy.gov.ru/material/file/cd5f022ea67a390179e34f08db68e58e/20200522_.pdf (18.07.2020).

Ministierstwo Ekonomiczieskowo Razwitija. (2020d). Makroekonomika w sowriemiennych usłowijach. Pobrano z https://www.economy.gov.ru/material/directions/ makroec/ (22.07.2020).

Ministerstwo Ekonomiczieskowo Razwitija. (2020e). O dynamikie promyszliennowo razwitija. Pobrano z https://www.economy.gov.ru/material/file/cd5f022ea67a390179e34f08db68e58e/20200522_.pdf (14.07.2020).

Ministierstwo Finansow. (2020a). Gosudarstwiennyj wniesznij dołg Rossijskoj Fiedieracii. Pobrano z https://minfin.gov.ru/ru/perfomance/public_debt/external/ (27.07.2020). 
Ministierstwo Finansow. (2020b). Gosudarstwiennyj wniesznij dołg Rossijskoj Fiedieracii. Pobrano z https://minfin.gov.ru/ru/perfomance/public_debt/internal/structure/ total/ (27.07.2020).

Nabiullina E. (2020). Tiekuszczaja situacija i stabilizacijonnyje miery, Press Konfieriencija, Bank Rossii, 24 ijulija 2020 g. Pobrano z https://cbr.ru/info_2020/press_info2020/ (09.08.2020).

Niedostatocznyj urowień kapitalizacii bankowskowo siektora. (b.d.). W: Sistiemnyje riski i aktualnyje problemy sowriemiennoj rossijskoj bankowskoj sistiemy (s. 1617). Pobrano z https://xn--90ab5f.xn--plai/common/upload/files/veb/analytics/ fld/20121203bank.pdf (12.07.2020).

Novoselova, M., Miroshnikova, L. Onoshko, O. (2015). Stratiegija sokraszczienija diejatielnosti kommerczieskich bankow. Izwiestija Irkutskoj Gosudarstwiennoj Ekonommiczieskoj Akademii, 5, 827-833. doi: 10.17150/1999-3541.2015.25(5)

Pojmanowa, L. (2018). Moszennicziestwo w bankowskoj sfierie. Irkutskij Gosudarstwiennyj Uniwiersytet, 2, 86-87.

Połbin, A., Sinielnikow-Muryliew, S., Trunin, P. (2020). Ekonomiczieskij krizis 2020 g.: pricziny i miery po jewo preodolieniuju i dalniejsziemu razwitiju Rossii. Woprosy Ekonomiki, 2, 34-44. doi: 10.32609/0042-8736-2020-6

RosStat. (2020a). O proizwodstwie i ispolzowaniju wałowo wniutriennowo produkta. (Fiedieralnaja Służba Gosudarstwiennoj Statistiki). Pobrano z https://www.gks. ru/bgd/free/B04_03/IssWWW.exe/Stg/d05/19.htm (12.07.2020).

RosStat. (2020b). Rynok truda, zaniatost i zarabatnaja płata. Pobrano z https://www.gks. ru/labor_market_employment_salaries?print=1 (16.07.2020).

RosStat. (2020c). Urowień biezraboticy w Rossii. Pobrano z https://visasam.ru/russia/ rabotavrf/bezrabotica-v-rossii.html (10.07.2020).

Sinielnikowa-Muryliewa, E., Grebienkina, A. (2020). Diskussija ob optimalnosti cielewowo urownia infliacii. Moskwa: Wiestnik Moskowskowo Uniwiersytieta im. Łomonosowa.

Skobielkin, D. (2019). Komunikat Banku Rossii, 17 ijunija 2019 g, Moskwa. Pobrano $\mathrm{z}$ https://cbr.ru/press/event/?id=5034 (16.06.2020).

Stiepanczenko, A. (2019). Prawowoje regulirowanije grażdanskowo oborota inostrannoj waliuty w Rossii. Moskwa.

Turdyjewa, N. (2020). Wozdiejstwieje szokow usłowij targowli na rossijskuju ekonomiku. Dieńgi $i$ Kriedit, 2, 43.

Uhlig, H. (2005). What are the effects of monetary policy on output? Results from an agnostic identification procedure. Journal of Monetary Economics, 52(2), 381-419.

Visanam (2020). Statistika i urowień biezraboticy w Rossii. Pobrano z https://visasam. ru/russia/rabotavrf/bezrabotica-v-rossii.html (10.07.2020). 
VnieshEkonomBank (2020). Makroanalitics - analiticzieskaja ocenka. Pobrano z: https:// xn--90ab5f.xn-plai/common/upload/files/veb/analytics/macro/201107b.pdf (28.06.2020).

Yandex (2020a). Skolko dienieg połuczit każdyj żitiel Rossii. Pobrano z https://zen.yandex. ru/media/investingjust/skolko-zarabatyvaiut-rossiiane-v-2020-godu-po-versii--rosstat-5f1547ebf3d6245056357cb2 (10.07.2020).

Yandex (2020b). Gosudarstwiennyj bank Rossii - kakije diengi uprawliajutsia gosudarstwom. Pobrano z yandex.ru/media/id/5ada408f1410c3a7dd480668/banki-s--gosudarstvennym-uchastiem-spisok-2018-5adaeab3bce67e90d2a45f08?utm_ source $=\operatorname{serp}(18.07 .2020)$.

Zubkow, I. (2020) Ekonomisty ocenili potiery ekonomiki Rossii ot koronawirusa. Rossijskaja gazieta, 12.04.2020, 4.

\section{Streszczenie}

Rosja jest znaczącym eksporterem surowców energetycznych, ropy naftowej i gazu. Jej gospodarka jest w bardzo dużym stopniu uzależniona od cen światowych tych produktów. Na początku 2020 r. ceny surowców energetycznych na świecie znacząco spadły, co mocno uderzyło w gospodarkę Rosji. Jest to też czas gwałtownego rozprzestrzenia się pandemii koronawirusa SARS-CoV-2. W artykule zaprezentowano konsekwencje, które dotknęły całą gospodarkę, a także sektor bankowy. Opisano działania, jakie podjął Bank Rosji w celu ochrony sektora bankowego i klientów. Wskutek pogarszającej się sytuacji finansowej bank centralny poluzował politykę pieniężną. W ten sposób skierował na rynek dodatkowe środki finansowe. Przyjęto też zasady, które umożliwiły bankom komercyjnym złagodzenie wymagań wobec klientów starających się o kredyty. Działania Banku Rosji i polityka kredytowa banków komercyjnych, skierowane na wspieranie gospodarki i ludności, łagodzą tylko częściowo skutki pandemii koronawirusa. W perspektywie najbliższych lat skuteczność podejmowanych wysiłków będzie zależeć od czynników występujących zarówno w gospodarce światowej, jak i wewnętrznej polityce gospodarczej Rosji oraz w charakterze i dynamice zmian umożliwiających stabilizowanie sektora bankowego.

SŁowA KLUCzowE: gospodarka, Rosja, SARS-oV-2, Bank Rosji, sektor bankowy.

\section{Summary}

Russia is a major exporter of energy resources, oil and gas. Its economy is very much dependent on world prices of these products. At the beginning of 2020, the prices of energy resources fell significantly all around the world, which hit the Russian economy hard. At the same time, the corona virus pandemic SARS-CoV-2 was spreading rapidly. The article presents the consequences that have affected the entire economy as well as the banking sector. It describes the actions taken by the Bank of Russia to protect both the banking sector and customers. As a result of the deteriorating financial situation, the central bank has loosened monetary policy. In this way, it has channeled additional 
financial resources to the market. Rules were also adopted that allowed commercial banks to ease the requirements for customers applying for credits. The actions of the Bank of Russia and the credit policy of commercial banks aimed at supporting the economy and the population only partially mitigate the effects of coronavirus pandemic. In the coming years, the effectiveness of the efforts will depend on factors in both global economy as well as Russia's internal economic policy as well as on the nature and dynamics of changes enabling stabilization of the banking sector.

KeYwords: Russian economy, SARS-CoV-2, Bank of Russia, banking sector.

Marian Żukowski - prof. dr hab., Katolicki Uniwersytet Lubelski Jana Pawła II, Kierownik Katedry Polityki Gospodarczej i Bankowości; główne obszary działalności naukowej: bankowość, finanse, system bankowy w Polsce i w krajach Europy Wschodniej, makroekonomia Rosji; e-mail: marian.zukowski@kul.pl; ORCID: 0000-0001-5724-4952. 